\title{
Bone Cancer Pathologic Distant Metastasis TNM Finding v8
}

National Cancer Institute

\section{Source}

National Cancer Institute. Bone Cancer Pathologic Distant Metastasis TNM Finding v8. NCI Thesaurus. Code C136570.

A pathologic finding about one or more characteristics of bone cancer, following the rules of the TNM AJCC V8 classification system as they pertain to distant metastases. 